\title{
Scaffolds of Calcium Phosphate Cement Containing Chitosan and Gelatin
}

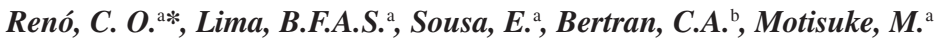 \\ ${ }^{a}$ Bioceramics Laboratory, Institute of Science and Technology, Federal University of \\ São Paulo - UNIFESP, São José dos Campos, SP, Brazil \\ ${ }^{\mathrm{b}}$ Physical Chemistry Department, Institute of Chemistry, University of Campinas - UNICAMP, \\ Campinas, SP, Brazil
}

Received: November 18, 2012; Revised: June 10, 2013

\begin{abstract}
Calcium phosphate cements (CPCs) have potential to be used on repairing damaged bones due to their moldability, bioactivity and bioresorbability. These materials combine calcium orthophosphate powders with a liquid leading to a paste that hardens spontaneously at low temperatures. Hence, CPCs could be applied as scaffolds to support cell/tissue growth. This paper studies CPC scaffolds processing by foaming cement's liquid phase in which was added gelatin and chitosan. The former acted to increase the foam stability while the ladder acted as a foaming agent. Moreover, these polymers would enhance scaffold's biological properties by controlling material's total porosity and in vivo resorption. The method proposed led to scaffolds with $58.71 \%$ porosity with sizes ranging from 160 to $760 \mu \mathrm{m}$ and compressive strength of 0.70MPa. After foaming, pores' size, distribution and interconnectivity changed significantly leading to a material that could be applied on bone regeneration since it would allow nutrient's transport, cell attachment and an increase in material degradation rate.
\end{abstract}

Keywords: scaffolds, calcium phosphate cements, gelatin, chitosan

\section{Introduction}

Calcium phosphate bioceramics present several applications in orthopedics since they provide implant's structural integrity holding it in place and intact while new bone tissue is growing. Their chemical composition provides interesting properties making them biocompatible, bioactive, resorbable and osteoconductive ${ }^{1}$.

In this context, calcium phosphate cements (CPCs) present appropriate characteristics to be used in repairing damaged bones. CPCs were introduced in the 1990s as a commercial product and since then, different formulations and applications have been developed ${ }^{2,3}$.

CPCs are formed by mixing calcium orthophosphate powders with a liquid phase resulting in a moldable paste that hardens spontaneously after a low temperature setting reaction ${ }^{2-4}$. One kind of CPCs is brushite cements, which are obtained after an acid-base reaction. The most common composition contains $\beta$-tricalcium phosphate $(\beta-\mathrm{TCP})$ and an acid, for example phosphoric acid. When $\beta$-TCP reacts incompletely, final composition is a mixture of $\beta$-TCP and brushite $^{2}$. One application of CPCs is scaffolds production, which facilitate cell infiltration and tissue growth ${ }^{4,5}$.

Gelatin and chitosan have been added to bone cement to optimize the foaming process during scaffolds fabrication ${ }^{6,7}$ and to enhance materials' mechanical and biological properties. Gelatin is a biocompatible and resorbable protein obtained from bovine collagen and employed as a foaming agent $^{6-8}$. Montufar et al have proposed the fabrication of CPC scaffolds by foaming gelatin in the liquid-phase of an apatite cement ${ }^{4}$. Foam stability was obtained by increasing wt.\% of gelatin. A different path to obtain foam stability is to

*e-mail: c.reno@unifesp.br employ chitosan ${ }^{7,9,10}$, a biopolymer originated from chitin; that is non-toxic, biodegradable, and biocompatible. It is insoluble in water or in body fluid, but soluble below $\mathrm{pH}$ 6.5 in most of the acidic mediums. Thus, the objective of this work was to synthesize and characterize scaffolds of calcium phosphate cement by foaming the liquid phase containing gelatin and chitosan.

\section{Material and Methods}

\subsection{Calcium Phosphate Cement (CPC) and scaffolds}

CPCs solid phase, $\beta$-TCP, was synthesized by solid state reaction of a stoichiometric mixture of $\mathrm{CaCO}_{3}$ (Synth, Brazil) and $\mathrm{CaHPO}_{4}$ (Synth, Brazil) at $1050{ }^{\circ} \mathrm{C}^{11,12}$ followed by ball milling during 48 hours $^{12}$. The resulting powder was analyzed by laser diffraction (Mastersizer 2000) and presented mean particle size of $3.6 \mu \mathrm{m}$ and granulometric distribution between $0.770 \mu \mathrm{m}$ and $20.843 \mu \mathrm{m}$.

Liquid phase consisted of an aqueous solution containing citric acid ${ }^{13}\left(\mathrm{C}_{6} \mathrm{H}_{8} \mathrm{O}_{7}\right.$, Synth, Brazil), phosphoric acid $\left(\mathrm{H}_{3} \mathrm{PO}_{4}\right.$, Synth, Brazil), chitosan (Sigma Aldrich, Germany) and gelatin (Synth, Brazil). Gelatin was employed as a foaming agent and chitosan was added to stabilize the foam ${ }^{9,10,14}$. All formulations are described in Table 1.

Powder and liquid phases were mixed for $1 \mathrm{~min}$ and molded into cylindrical silicone molds (20X10mm). After setting, samples were polished and demolded. For sample BC0.5Gf, the liquid phase was stirred for 1 minute using UltraTurrax Tube Disperser (IKA ${ }^{\circledR}$-WERKE, Germany) before mixing it with the powder. 


\subsection{Characterization}

Crystalline phases formed during CPCs setting reaction were analyzed by $\mathrm{X}$-ray diffraction (X'Pert Pro - PANalytical- X'Celerator, CuK $\alpha$, Ni filter, 10 a $50^{\circ}$ $(2 \theta), 0.02 \% \mathrm{~s}, 45 \mathrm{kV}$ e $40 \mathrm{~mA})$. JCPDS files used for phase identification were 09-0077 for brushite, 09-0080 for monetite and 09-0169 for $\beta$-TCP.

Samples chemical composition were investigated using attenuated total reflection (ATR) with iS5-Nicolet Thermo FT-IR spectrometer with a scanning range of 550 to $4000 \mathrm{~cm}^{-1}$ and resolution of $2 \mathrm{~cm}^{-1}$.

Moreover, CPC and scaffolds were mechanically tested (EMIC DL2000, tesc version 3.04, $0.5 \mathrm{~mm} \cdot \mathrm{min}^{-1}, 10 \mathrm{kN}$ ) and morphology of the fracture surface was analyzed by scanning electron microscopy (JEOL-6400) with the samples coated with gold (Baltec MCS010). Total porosity was determined by Arquimedes' method.

\section{Results and Discussions}

Foaming CPC liquid phase allowed scaffold formation. As observed in Figure 1, gelatin increased material's total porosity even with no foaming. Scaffolds were obtained only with $0.5 \mathrm{wt} . \%$ of gelatin since higher concentrations lowered mechanical resistance and formed higher volumes of foam that prevented cement's setting. Furthermore, chitosan addition was necessary in order to maintain the foam stability by gelling CPC liquid phase and avoiding the collapse of the porous structure during cement setting ${ }^{9,10}$.

Samples without gelatin (B and BC) exhibited lower porosity than those containing gelatin $(\mathrm{BC} 0.5 \mathrm{G}, \mathrm{BC} 1 \mathrm{G}$, BC0.5Gf). As seen in Figure 1, samples B and BC0.5Gf

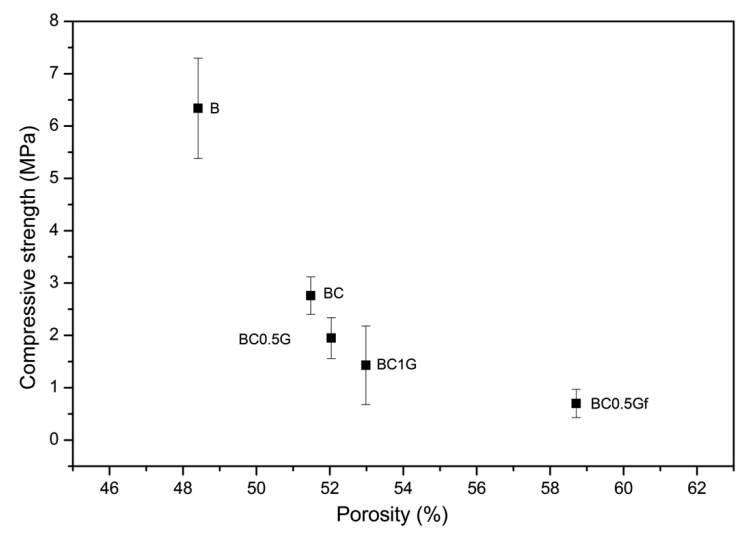

Figure 1. Compressive strength of samples as a function of porosity. presented $48 \%$ and $59 \%$ of total porosity, respectively. Besides of increasing sample total porosity, foaming also created larger and broader interconnected pores that might promote nutrients' transport and the enlargement of cell interaction surface area facilitating new bone growth ${ }^{6,14,15}$. This can be observed in the SEM micrographs (Figure 2) of the surface of fracture of the set cements with and without chitosan, gelatin and foaming.

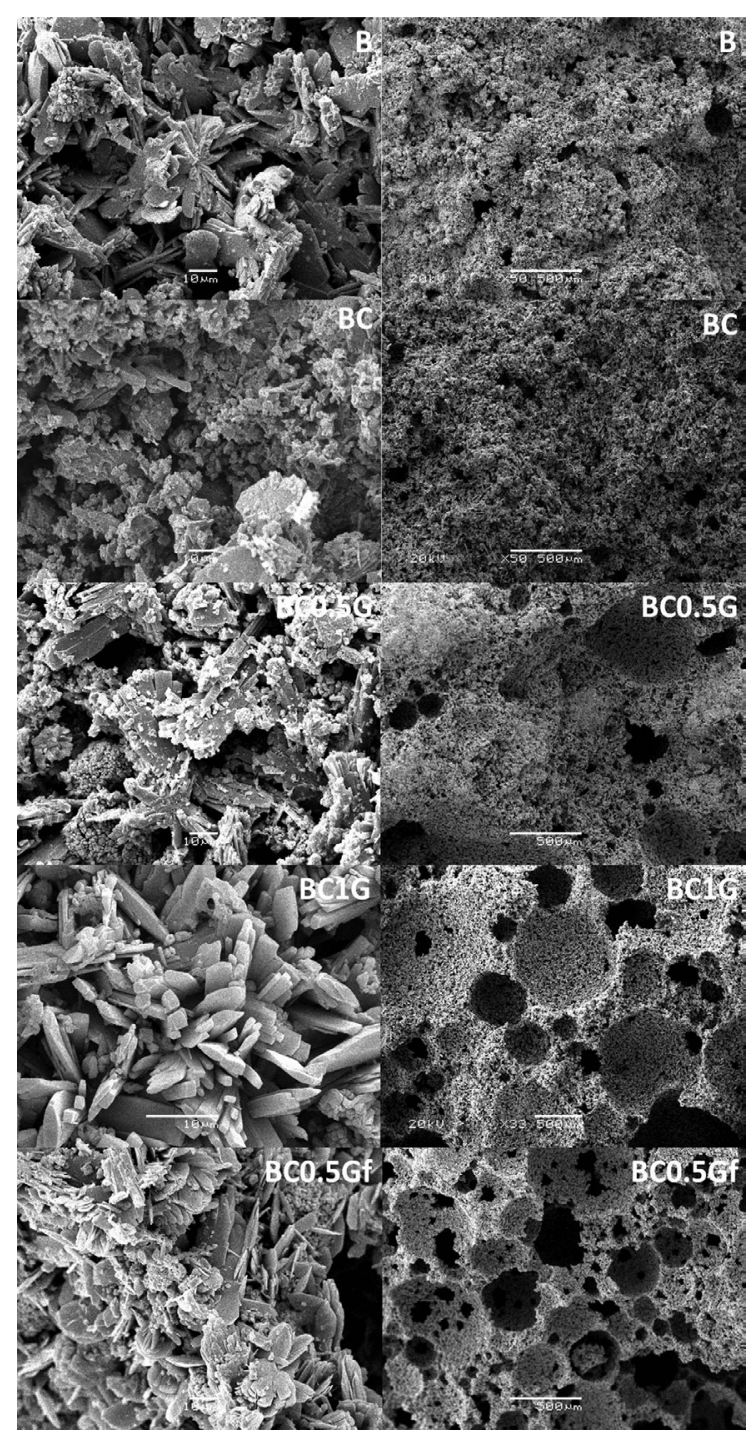

Figure 2. SEM micrographs of samples' surface of fracture.

Table 1. CPC and scaffold formulation.

\begin{tabular}{|c|c|c|c|c|c|c|}
\hline \multirow[b]{2}{*}{ Sample } & \multicolumn{4}{|c|}{ Liquid Phase } & \multirow{2}{*}{$\begin{array}{l}\text { liquid-to- } \\
\text { powder ratio } \\
(\mathrm{mL} / \mathrm{g})\end{array}$} & \multirow[b]{2}{*}{ Foaming } \\
\hline & $\begin{array}{c}\mathrm{C}_{6} \mathrm{H}_{8} \mathrm{O}_{7} \\
(\mathrm{wt}-\%)\end{array}$ & $\begin{array}{c}\mathrm{H}_{3} \mathrm{PO}_{4} \\
\text { (wt-\%) }\end{array}$ & $\begin{array}{c}\text { Chitosan } \\
\text { (wt-\%) }\end{array}$ & $\begin{array}{l}\text { Gelatin } \\
\text { (wt-\%) }\end{array}$ & & \\
\hline B & & & 0 & 0 & & No \\
\hline $\mathrm{BC}$ & & & 0.5 & 0 & & No \\
\hline $\mathrm{BC} 1 \mathrm{G}$ & 1.54 & 26.16 & 0.5 & 1 & 0.80 & No \\
\hline $\mathrm{BC} 0.5 \mathrm{G}$ & & & 0.5 & 0.5 & & No \\
\hline BC0.5Gf & & & 0.5 & 0.5 & & Yes \\
\hline
\end{tabular}


Scaffolds with pore diameters ranging from 100 to $800 \mu \mathrm{m}$ facilitate cell attachment and proliferation ${ }^{16,17}$. Moreover, making scaffolds of resorbable materials enhance its degradation rate permitting new bone tissue growth and improving implant osteointegration ${ }^{6,14-16,18}$. Fortunately, all samples containing gelatin have pore size distribution between the ideal range (100 to $800 \mu \mathrm{m})$. Nevertheless, foamed sample presented larger, more homogeneous and interconnected pores, ranging from 160 to $760 \mu \mathrm{m}$.

As expected, compressive strength decreased with porosity increase, as seen in Figure 1. Chitosan promoted a $60 \%$ decrease in compressive strength. Samples with gelatin presented a decrease of $30 \%(\mathrm{BC} 0.5 \mathrm{G})$ and $50 \%$

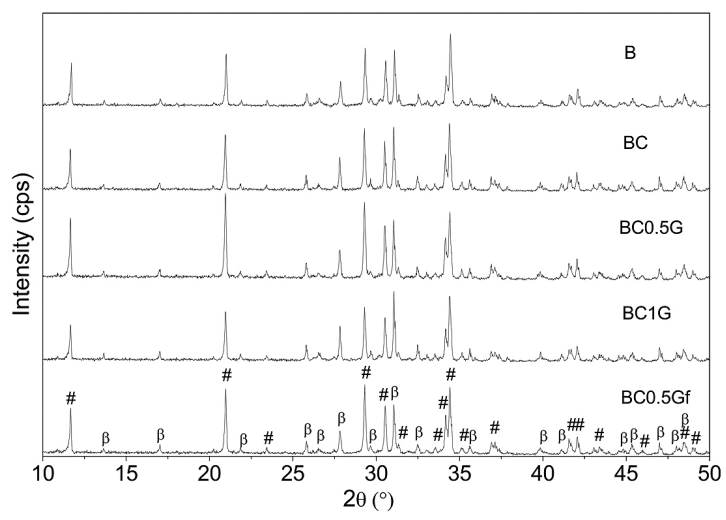

Figure 3. Powder $X$-ray diffraction patterns of cement and scaffold samples. Legend = $\beta: \beta-$ TCP, \#: Brushite.

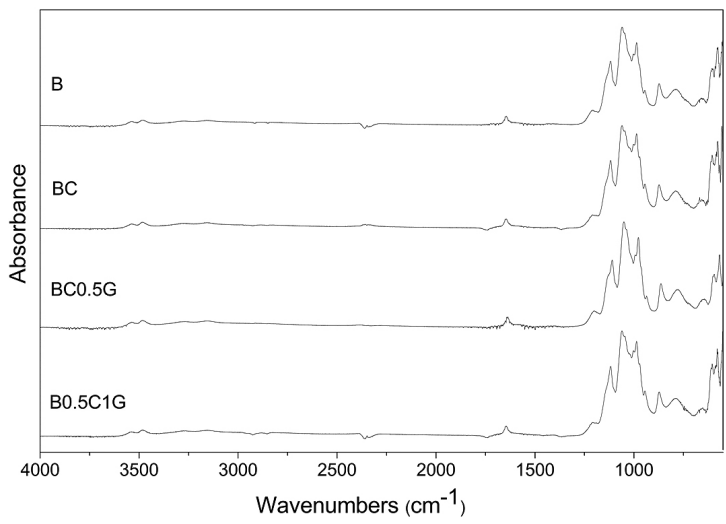

Figure 4. ATR-IR spectra of cements.

\section{References}

1. De Aza PN, De Aza AH and De Aza S. Crystalline bioceramic materials. Boletin de la Sociedad Española de Cerámica y Vidrio. 2005; 44(3):135-145. http://dx.doi.org/10.3989/ cyv.2005.v44.i3.382

2. Ginebra MP, Cana C, Espanhol M, Pastorino D and Montufar EB. Calcium phosphate cements as drug delivery materials. Advanced Drug Delivery Reviews. 2012; 64(12):1090-1110. http://dx.doi.org/10.1016/j.addr.2012.01.008
(BC1G) in mechanical resistance compared to sample BC. Finally, compressive strength of foamed sample was $0.70 \pm 0.27 \mathrm{MPa}$. Nevertheless, materials' compressive strength remained close to the range of cancellous bone $(1-12 \mathrm{MPa})^{19}$. Further studies varying stirring speed and time are necessary to control material's total porosity and, consequently, to enhance material's mechanical properties.

Cement setting reaction took place as expected; $\beta$-TCP has reacted with $\mathrm{H}_{3} \mathrm{PO}_{4}$ to form brushite $\left(\mathrm{CaHPO}_{4} \cdot 2 \mathrm{H}_{2} \mathrm{O}\right)$ as shown in the XRD patterns of Figure $3^{2}$ and ATR-IR spectra of Figure $4^{20}$.

The presence of gelatin and chitosan after setting reaction could not be detect in ATR-IR analysis (Figure 4), because of their low concentration ${ }^{21,22}$. The bands that were present in ATR-IR spectra of the cement samples are characteristic of brushite: the O-H stretching of crystallization water could be detected with double bands at $3540,3485 \mathrm{~cm}^{-1}$, and the $\mathrm{H}-\mathrm{O}-\mathrm{H}$ bending had absorption at $1651 \mathrm{~cm}^{-1}$. The $\mathrm{PO}_{4}$ group has characteristic bands at 1140,1066, $990 \mathrm{~cm}^{-1}$, caused by $\mathrm{PO}$ stretching modes of the $\mathrm{PO}_{3}$ fragment. At 1210 and $875 \mathrm{~cm}^{-1}$, bands characterizing $\mathrm{P}-\mathrm{O}(\mathrm{H})$ stretching and in plane $\mathrm{P}-\mathrm{O}-\mathrm{H}$ bending. Below $650 \mathrm{~cm}^{-1}$, the bands represent the $\mathrm{PO}$ deformation of the tetrahedral $\mathrm{PO}_{4}$ group ${ }^{20}$.

\section{Conclusions}

CPC scaffold was obtained by foaming cement liquid phase containing $0.5 \mathrm{wt} \%$ of gelatin. Interconnected pores ranging from 160 to $760 \mu \mathrm{m}$ were obtained. As expected, the compressive strength has decreased as a function of porosity increase.

Total porosity had significantly increased after foaming, directly affecting the size distribution and interconnectivity of the pores, leading to a material that could be applied to bone regeneration, since it would allow transport of nutrients, cell attachment and material's degradation rate increases. Chitosan addition was effective since it promoted foam stability and permitted scaffolds fabrication with lower contents of gelatin.

\section{Acknowledgements}

The authors would like to thank The São Paulo Research Foundation (FAPESP) for the financial support (Process number 2011/09240-9) and João Paulo Barros Machado, PhD from the Laboratory of Sensors and Materials (LAS) of the National Institute of Space Research (INPE) for permitting XRD analysis.

3. Ginebra MP, Espanhol M, Montufar EB, Perez RA and Mestres G. New processing approaches in calcium phosphate cements an their applications in regenerative medicine. Acta Biomaterialia. 2010; 6(8):2863-2873. http://dx.doi. org/10.1016/j.actbio.2010.01.036

4. Montufar EB, Traykova T, Planell JA and Ginebra MP. Comparison of a low molecular weight and a macromolecular surfactant as foaming agents for injectable self setting hydroxyapatite foams: Polysorbate 80 versus gelatine. 
Materials Science and Engineering C. 2011; 31(7):1498-1504. http://dx.doi.org/10.1016/j.msec.2011.06.008

5. Machado JLM, Benderovics G and Santos LA. Obtenção de suporteparaengenharia de tecidosutilizando-se cimento de $\alpha$-trifosfato de cálcio ( $\alpha$-TCP). In: Proceedings of 17thCBECiMat - Brazilian Congress of Engineering and Science of Materials; 2006; Foz do Iguaçu, Brazil. Foz do Iguaçu; 2006. p. 156-167.

6. Shie MY, Chen DCH, Wang CY, Chiang TY and Ding SJ. Immersion behavior of gelatin-containing calcium phosphate cement. Acta Biomaterialia. 2008; 4(3):646-655. http://dx.doi. org/10.1016/j.actbio.2007.10.011

7. Chiang TY, Ho CC, Chen DCH, Lai MH and Ding SJ. Physicochemical properties and biocompatibility of chitosan oligosaccharide/gelatin/calcium phosphate hybrid cements. Materials Chemistry and Physics. 2010; 120(2-3):282-288. http://dx.doi.org/10.1016/j.matchemphys.2009.11.007

8. Big A, Bracci B, Panzavolta S. Effect of added gelatin on the properties of calcium phosphate cement. Biomaterials. 2004; 25(14):2893-2899. http://dx.doi. org/10.1016/j.biomaterials.2003.09.059

9. Hamdine M, Heuzey MC and Bégin A. Effect of organic and inorganic acids on concentrated chitosan solutions and gels. International Journal of Biological Macromolecules. 2005; 37(3):134-142. http://dx.doi. org/10.1016/j.ijbiomac.2005.09.009

10. Leffler CC, Muller BW. Influence of the acid type on the physical and drug liberation properties of chitosan-gelatin sponges. International Journal of Pharmaceutics. 2000; 194(2):229-237. http://dx.doi.org/10.1016/S0378-5173(99)00383-X

11. Oliveira AP, Motisuke M, Leal CV and Beppu MM. A Comparative study between $\beta$-TCP prepared by solid statereaction and by aqueous solution precipitation: application in cements. Key EngineeringMaterials. 2008; 361-363:355-358. http://dx.doi.org/10.4028/www.scientific.net/KEM.361-363.355

12. Cardoso HAI, Motisuke M and Zavaglia CAC. Análise da influência de dois processos distintos de moagem nas propriedades do pó precursor e do cimento de beta-TCP. Cerâmica. 2012; 58(346):225-228. http://dx.doi.org/10.1590/ S0366-69132012000200013

13. Bohner M, Merkle HP, Van Landuyt P, Trophardy G and Lemaitre J. Effect of several additives and their admixtures on the physicchemical properties of calcium phosphate cement. Journal of Materials Science: Materials in Medicine. 2000; 6:111-116. http://dx.doi.org/10.1023/A:1008997118576
14. Montufar EB, Traykova T, Gil C, Harr I, Almirall A, Aguirre A et al. Foamed surfactant solution as a template for self-setting injectable hydroxyapatite scaffolds for bone regeneration. Acta Biomaterialia. 2010; 6(3):876-885. http://dx.doi.org/10.1016/j. actbio.2009.10.018

15. Heredia MAL, Sariibrahimoglu K, Yang W, Bohner M, Yamashita D, Kunstar A et al. Influence of the pore generator on the evolution of the mechanicalproperties and the porosity and interconnectivity of a calcium phosphate cement. Acta Biomaterialia. 2012; 8(1):404-414. http://dx.doi.org/10.1016/j. actbio.2011.08.010

16. Sous M, Bareille R, Rouais F, Clément D, Amédée J, Dupuy $\mathrm{B}$ and Baquey C. Cellular biocompatibility and resistance to compression of macroporous $\beta$-tricalcium phosphate ceramics. Biomaterials. 1998; 19(23):2147-2153. http://dx.doi. org/10.1016/S0142-9612(98)00118-5

17. Zhou Y, Xu L, Zhang X, Zhao Y, Wei S and Zhai M. Radiation synthesis of gelatin/CM-chitosan/ $\beta$-tricalciumphosphate composite scaffold for bone tissue engineering. Materials Science and Engineering: C. 2012; 32(4):994-1000. http:// dx.doi.org/10.1016/j.msec.2012.02.029

18. Fernández E, Vlad MD, Gel M M, López J, Torres R, Cauich JV and Bohner M. Modulation of porosity in apatitic cements by the use of $\alpha$-tricalcium phosphate-calcium sulphatedihydrate mixtures. Biomaterials. 2005; 26(17):3395-3404. http://dx.doi. org/10.1016/j.biomaterials.2004.09.023

19. Myoui A, Tamai N, Nishikawa M, Hideki Y, Araki N, Nakase $\mathrm{T}$ et al. Three-Dimensionally Engineered Hydroxyapatite Ceramics with Interconnected Pores as a Bone Substitute and Tissue Engineering Scaffold. In: Biomaterials in Orthopedics. Marcel Dekker, Inc.; 2004. p. 287-300.

20. Cama G, Barberis F, Botter R, Cirillo P, Capurro M, Quarto $\mathrm{R}$ et al. Preparation and properties of macroporousbrushite bone cements. Acta Biomaterialia. 2009; 5(6):2161-2168. http://dx.doi.org/10.1016/j.actbio.2009.02.012

21. Hashim D M, Che Man Y B, Norakasha R, Shuhaimi M, Salmah Y and Syahariza ZA. Potential use of Fourier transform infrared spectroscopy for differentiation of bovine and porcine gelatins. Food Chemistry. 2010; 118(4):856-860. http://dx.doi. org/10.1016/j.foodchem.2009.05.049

22. Zawadzki J and Kaczmarek H. Thermal treatment of chitosan in various conditions. CarbohydratePolymers. 2010; 80(2):394-400. http://dx.doi.org/10.1016/j.carbpol.2009.11.037 